\title{
Coverture and the Marital Partnership in Late Medieval Nottingham: Women's Litigation at the Borough Court c.1300-c.1500
}

\section{Abstract}

Women engaged in litigation in Nottingham's borough court for a variety of reasons relating to trade, household provisioning, misbehaviour and interpersonal disputes, as both plaintiffs and defendants. This study examines how women's litigation was determined by the doctrine of coverture and the way that women's marital status shaped and defined their experience of the law. In doing so, it explores how these pleas reveal the workings of the marital partnership within a late medieval English town. In order to contextualise the experiences of women "under coverture", the article first traces the ways in which all manner of female marital and household identities were documented in the court records, analysing the descriptors attached to individual women's names by court scribes. The study highlights inconsistency in the way that women's identities were recorded and in the way that the marital partnership was represented through the litigation of spouses in the borough court. The dual focus of this article means that it not only adds new evidence to ongoing discussions of the nature of medieval coverture, but also asks questions about how we identify coverture and women's marital statuses based on the evidence of court records.

At Nottingham's borough court in 1374, William de Hontesdon sued Godesman Taylor and his wife Elena for a debt of 11s. William claimed that he had delivered a barrel of herring worth 11s. to the couple for Elena to sell, but they detained the herring, or (more 
likely) the profit from its sale. ${ }^{1}$ We might read this as evidence of the legal dominance of husbands over their wives, encapsulated in the doctrine of coverture. However, it also demonstrates that married women were not hidden from view in legal documents, and that their husbands did not simply act on their behalf. Instead, the actions of the Taylors and the inclusion of Elena in the complaint reveal her economic activity and the couple's joint accountability when the agreed transaction broke down. Despite the well-known rules of coverture that governed the relationship between husband and wife, limiting the legal capabilities of married women and instead assigning responsibility to the husband as her representative, borough records such as these reveal the legal actions of hundreds of married women who were not simply "covered" by their husbands. ${ }^{2}$ The records also document the

${ }^{1}$ CA1278 rot.22, Nottinghamshire Archives (hereafter NA). 11s. would have paid for a substantial amount of fish: in South Staffordshire in 1461, herring cost 1/4d. each, so $11 \mathrm{~s}$. equates to 528 herring. See Christopher Dyer, Everyday Life in Medieval England (London, 1994), 106. This sum was also greater than the annual rent for a messuage (8s.) in the town in 1374. CA1278 rot.17, NA.

${ }^{2}$ On coverture see Tim Stretton and Krista Kesselring "Introduction: Coverture and Continuity" in Married Women and the Law: Coverture in the Common Law World, ed. Tim Stretton and Krista J. Kesselring (London, 2013), 3-23; Tim Stretton, "Coverture and Unity of Persons in Blackstone's Commentaries" in Blackstone and his Commentaries: Biography, Law, History, ed. Wilfred Prest (Oxford, 2009), 111-128; Stretton, “The Legal Identity of Married Women in England and Europe 1500-1700" in Europa und seine Regionen: 2000 Jahre Rechtsgeschichte, ed. Andreas Bauer and Karl H. L. Welker (Cologne, 2006), 309-322; Sara M. Butler, "Discourse on the Nature of Coverture in the Later Medieval Courtroom," in Married Women and the Law, ed. Stretton and Kesselring, 39-40; Cordelia Beattie, "Married 
actions and identities of numerous other women who were not married, but were instead recorded under a range of different descriptors that were used to identify their status at court. Together, these pleas offer insights into the ways that coverture was understood and applied in the borough court during the late medieval period and the role that marital status played in shaping women's experiences of the law.

To unpick the nature of coverture in Nottingham's borough court this study begins by examining the descriptors applied to the names of female litigants and critically considers how we identify coverture in the extant records. The various means of documenting married and non-married women's presence in the court records is central to our broader understanding and contextualisation of the power of coverture and the role that marital status played in defining women's legal actions. To assess married women's varying roles in litigation the article then focuses on actions of debt and trespass in the borough court over the fourteenth and fifteenth centuries, offering a new perspective on the marital partnership and the various ways that this was represented under local law. Litigation in Nottingham arose from the innumerable, individual interactions of daily life, with the majority of cases relating to trade or misbehaviour within the urban community. The court records thus make visible the obligations, restrictions and expectations of married women and their husbands at the lowest level of England's legal hierarchy. While various studies have focussed on women's involvement in one type of complaint (usually debt), this combined analysis allows for a more complete picture of wives' legal actions and responsibility in a range of situations, from the repayment of debts to the implications of a physical assault.

Women, Contracts and Coverture in Late Medieval England", in Married Women and the Law in Premodern Northwest Europe, ed. Cordelia Beattie and Matthew Frank Stevens (Woodbridge, 2013) 133-154. 
Discussions of coverture are largely structured around the disabilities imposed upon women by common law, often listing the numerous things that married women could not do, at least in theory. ${ }^{3}$ However, studies of women's litigation in practice have identified the various means by which married women did take legal action, despite these theoretical limitations. This apparent contradiction is a symptom of the often messy relationship between "lived lives", law in practice, and legal theory. The thirteenth-century legal treatise known as Bracton, describing the nature of English law, had little to say on the practical legal rights of married women, but set out the dual nature of coverture under common law: husband and wife were a "single person, because they are one flesh and one blood", and men were the rulers of their wives and custodians of their property. ${ }^{4}$ This meant that wives were unable to bring or answer complaints independently, except in a few extreme circumstances such as the murder of their husband. ${ }^{5}$ However, as Tim Stretton has argued, the "practical fiction" of unity of flesh and blood did not mean that wives were not legal persons in reality or that they lacked the ability to wage law; instead, the essence of coverture in the middle ages lay in the power a husband wielded over his wife and her property. ${ }^{6}$ Stretton has also highlighted how

\footnotetext{
${ }^{3}$ See the introduction to Marital Litigation in the Court of Requests, 1542-1642, ed. Tim
} Stretton (Cambridge, 2008), 2-6.

${ }^{4}$ Henry de Bracton, On the Laws and Customs of England, trans. S.E. Thorne, 4 vols. (Cambridge, MA, 1968-77), 4, 287. On the writing of the treatise see J.L. Barton, "The mystery of Bracton," The Journal of Legal History 14, no. 3 (1993): 1-142.

${ }^{5}$ Bracton, vol. 2, 353.

${ }^{6}$ Tim Stretton, “Coverture and Unity of Persons in Blackstone's Commentaries" in Blackstone and his Commentaries: Biography, Law, History, ed. Wilfred Prest (Oxford, 2009), 112, 115. 
coverture in theory often differed from the practices of everyday life, by which many wives were able to independently earn money, buy and sell, accept gifts and regard property as their own - something that Cordelia Beattie has recently illuminated through the wills of married women. ${ }^{7}$ Understanding the workings of coverture in practice thus requires us to attend to "the lived reality of actual, as opposed theoretical" women, as revealed by court records. ${ }^{8}$ This has been the focus of various studies, revealing the flexibility and grey areas of coverture as applied in various courts, and the means by which this "ubiquitous misogyny" could be mitigated and negotiated. ${ }^{9}$ But despite its inconsistent application, coverture

${ }^{7}$ Tim Stretton, "The legal identity of married women in England and Europe 1500-1700" in Europa und seine Regionen, eds. Andreas Bauer and Karl H. L. Welker (Cologne, 2007), 312-3; Cordelia Beattie, “Married Women's Wills: Probate, Property and Piety in Later Medieval England", Law and History Review (2019): 1-32.

${ }^{8}$ Sara M. Butler, "Medieval Singlewomen in Law and Practice," in The Place of the Social Margins, 1350-1750, ed. Andrew Spicer and Jane L. Stevens Crawshaw, (Abingdon, 2016), $59-78$ at 60.

${ }^{9}$ Butler, "Discourse on the Nature of Coverture" 39-40. See also Beattie, "Married Women, Contracts and Coverture,” 133-154; Matthew Frank Stevens, “London’s Married Women, Debt Litigation and Coverture in the Court of Common Pleas," in idem, 115-132; on early modern women see Cathryn Spence, "For His Interest'? Women, Debt and Coverture in Early Modern Scotland," in Married Women and the Law, ed. Beattie and Stevens, 173-190; Joanne Bailey, “Favoured or Oppressed? Married Women, Property and 'Coverture' in England, 1660-1800," Continuity and Change 17, no. 3 (December, 2002): 351-371; Amy Louise Erickson, "Coverture and Capitalism," History Workshop Journal 59, no. 1 (Spring, 
nevertheless exercised considerable power and influence over the operation of law in practice, in both common law jurisdictions and beyond. ${ }^{10}$ Medieval coverture was thus something of a slippery concept that does not lend itself to straightforward definitions, but was instead negotiated by the numerous individuals, officials, and jurisdictions that operated within the English legal system. The records of provincial borough courts allow us to add the experiences of a large number of urban women and their everyday disputes to this everevolving historical conversation.

Borough courts sat at the lowest level of England's complex legal hierarchy. They heard relatively minor civil complaints arising from the everyday interactions of urban dwellers. Borough courts did not have jurisdiction over more severe pleas relating to felonies or high value debts (above 40s.) and they offered easy, local access to the law for those living in towns, not just the wealthy, making them central to ordinary working people's experiences of justice. Nottingham's borough court was just one of hundreds of local courts that existed across medieval England, each operating according to its own customs and practices. The focus on one court allows us to explore the experiences of women in the town in detail and raises important questions for the understanding of women's legal status across the multitude of jurisdictions that existed during the period that might be considered in relation to courts elsewhere. The records of Nottingham's court survive in considerable volume across the fourteenth and fifteenth centuries, making this an ideal location for in-depth study. The court was dominated by commercial complaints of debt, detinue and covenant, all originating from

2005): 1-16; Margot Finn, "Women, Consumption and Coverture in England, c.1760-1860," The Historical Journal 29, no. 3 (September 1996): 703-722.

${ }^{10}$ Stretton and Kesselring, "Introduction: Coverture and Continuity," 15; Sara M. Butler, Divorce in Medieval England: From One to Two Persons in Law (Abingdon, 2013), 12. 
the innumerable business and trading transactions that characterised urban life. ${ }^{11}$ It also heard complaints of trespass, a broad category of wrongdoing encompassing physical and verbal assault, theft, and attacks on property. ${ }^{12}$ The records are brief and formulaic, but they nevertheless serve as an unparalleled resource for studying the lives of ordinary urban women during the late medieval period.

\section{IDENTIFYING WOMEN AND COVERTURE}

Any assessment of the nature of coverture rests on our knowledge of individual women's identities and the way their status was recorded in legal sources. The differing statuses of medieval women are often discussed via the "maid-wife-widow" model, which divides women into three key marital categories over the course of the life cycle, mapping their lives as a series of transitions between different marital stages. ${ }^{13}$ This system of

${ }^{11}$ Richard Goddard, "Surviving Recession: English Borough Courts and Commercial Contraction, 1350-1500," in Survival and Discord in Medieval Society: Essays in Honour of Christopher Dyer, ed. Richard Goddard, John Langdon and Miriam Müller (Turnhout, 2010), 69-88.

${ }^{12}$ On the definition of trespass see George E. Woodbine, "The Origins of the Action of Trespass," The Yale Law Journal 33 (June, 1924): 799-816 at 802. Phillip Schofield, "Trespass Litigation in the Manor Court in the Late Thirteenth and Early Fourteenth Centuries," in Survival and Discord, ed. Goddard, Langdon and Müller, 145-160 at 147-152.

${ }^{13}$ Cordelia Beattie, Medieval Single Women: The Politics of Social Classification in Late Medieval England (Oxford, 2007), 3, 15-16; Butler, "Medieval Singlewomen," 60. See also Jane Laughton "Women in Court: Some Evidence from Fifteenth-Century Chester," 
classification reflected the patriarchal attitudes that underpinned female status and defined women via their relations to men and far less often by their occupation or social status (unlike men). The nature of the court records and lack of biographical details beyond individuals' names means that the way in which a woman's name was recorded - as wife, widow, daughter, singlewoman, or with no descriptor at all - is often the only means by which we can make an assessment of her marital status. These status identifiers were both inherent parts of individual identity, but also signalled a woman's legal status and her capacity to act independently in court (or not). However, as this study will show, the apparent tripartite model of female status was not employed consistently in documenting women's names when they appeared in court, and so the presence or lack of these descriptors (such as wife, widow, or singlewoman) should not be used to make assumptions about female status without careful consideration of how and why these descriptors were or were not applied in different cases. Amy Erickson has identified a similar problem in relation to the early use of the title "Mrs" and the distinct lack of rules concerning its usage. ${ }^{14}$ These terms and categories were culturally constructed in relation to specific legal and social contexts, helping to account for their varying and differing usage. ${ }^{15}$

Rather than a neat trichotomy, at least 10 different descriptors were applied to women's names in late medieval Nottingham. Some of these defined them in relation to men, but others did not. They were recorded by name only, as wife, widow, executrix, daughter,

Harlaxton Medieval Studies, IV (1994), 89-99 at 91; Caroline Dunn, Stolen Women in Medieval England: Rape, Abduction, and Adultery, 1100-1500 (Cambridge, 2013), 52.

${ }^{14}$ Amy Louise Erickson, "Mistresses and Marriage: or, a Short History of the Mrs," History Workshop Journal 78 (October 2014): 39-57.

${ }^{15}$ Beattie, Medieval Single Women, 14. 
singlewoman, "sole", servant, as well as by their occupation, or as "huswyf". ${ }^{16}$ Many of these descriptors were only used incidentally, but the five most commonly used descriptors have been sampled across a range of years and are displayed in the graph below. ${ }^{17}$ While these patterns may indicate changing attitudes and preferences in the documenting of female status, there was also an element of choice on the part of scribes about which labels to apply. ${ }^{18}$

\section{[INSERT FIGURE 1 HERE]}

The vast majority of women were recorded either by name alone (up to 59 per cent), or as wives (up to 60 per cent). ${ }^{19}$ While other possibilities did exist, most women were thus defined according to a binary division of female status: they were simply married or not

${ }^{16}$ Ellen Kittell found 14 different status identifiers applied to women in medieval Douai: citizen, daughter, companion, popular epithet, kin, location, spouse, mother, occupation, religious affiliation, sibling, social class, and no description at all. Ellen E. Kittell, "The Construction of Women's Social Identity in Medieval Douai: Evidence from Identifying Epithets," Journal of Medieval History 25, no. 3 (September 1999): 215-227 at 218-9. 17 These samples have been selected at intervals across the fourteenth and fifteenth centuries where the court records are relatively complete in order to provide the most accurate overview of all female names recorded each year. A small number of women in each sample have been counted under multiple categories where they were described using more than one term, for example by name alone and as daughter or widow.

${ }^{18}$ Beattie, Single Women, 3

${ }^{19}$ Source: CA1262, CA 1279, CA1296, CA1322I, CA1374, NA. 
married. The large group of women recorded by name alone challenges the assumption that women were always classified and understood via their relationship to a man, while the significant proportions of women recorded as wives, who litigated jointly with their husbands, reveal the extent of married women's action in the borough court. It is noteworthy that the numbers of wives recorded fell in the fifteenth century, indicating a real decline in joint litigation of married couples, as it was these cases in which women were described as "wife".

There was notable variation in the use of different descriptors over the period. At the same time that the number of wives fell, the proportion of women recorded by name only increased, reflecting the proportional decline in the litigation of married women alongside their husbands. These women were more than likely to have been unmarried women, and therefore not under coverture, though whether they were single women who had never (or not yet) married, or widows, was not deemed a necessary additional detail in most instances. However, the proportion of women described specifically as widows did increase by the end of the fifteenth century, which may point to a rise in the actual number of widows using the court, but also signals increasing attention paid to documenting the specific legal status of individual women. The fluctuating use of this category warrants further attention: while 28 per cent of women in court in 1491-2 were termed "widow", a decade earlier there had been none. ${ }^{20}$ The specific references to women described as "widow" do not necessarily indicate the only widows who used the court in a given year, and various studies of widowhood have highlighted their important role and competency in managing the businesses of their late husbands as well as in asserting their customary rights, and this may have drawn them into

${ }^{20} \mathrm{CA} 1370, \mathrm{NA}$. 
litigation. ${ }^{21}$ Instead, it is likely that this shift reflected the differing choice or tendency for scribes to describe women specifically as widows, or simply by their full name, impacting upon their visibility within the legal records.

Studies of widowhood have suggested that this was the best documented part of a woman's life cycle, highlighting the enhanced visibility and presence of widows in legal records and other sources due to their "transformation" in status from covered to independent. ${ }^{22}$ However, the Nottingham court records present a different and more complicated picture, suggesting that the details of women's widowed status were not always deemed relevant. There may well have been plenty of widows using the court, but the relative lack of widow descriptors suggests that this specific life cycle status was not rigorously recorded. Some widows were interchangeably referred to as widow, by their full name, or as "wife". Within the space of a few weeks, Margery, widow of John Fox was also called the wife of John Fox, as well as his executrix. ${ }^{23}$ She may have been very recently widowed, though the fact that she pleaded alone when termed "wife" suggests that her husband had already died by this point, and that this was instead a legacy of her former marital status. For

${ }^{21}$ Caroline M. Barron, "Introduction: The Widow's World in Later Medieval London” in Medieval London Widows 1300-1500, ed. Caroline M. Barron and Anne F. Sutton (London, 1994), xii-xxxiv.

${ }^{22}$ Mavis E. Mate, Daughters, Wives, and Widows after the Black Death Women in Sussex, 1350-1535 (Woodbridge, 1998), 94; Barron and Sutton, Medieval London Widows, xii; Tim Stretton, "Widows at Law in Tudor and Stuart England" in Widowhood in Medieval and Early Modern Europe, ed. Sandra Cavallo and Lyndan Warner (Harlow, 1999), 193-208 at 195.

${ }^{23}$ CA1291 rots.9, 10d, 11d, 18, 19 (all NA). 
some women, like Margaret Stapulton, we can trace the shift from wife to widow more clearly. In November 1390, Matilda de Barley brought a plea of covenant against Hugh de Stapulton and Margaret, though Matilda and Hugh settled the complaint alone. ${ }^{24}$ By March 1391, Margaret was the widow ("que fuit uxor") of Hugh Stapulton, when she sued Thomas de Coventre for a debt of 32d. concerning arrears owed to her late husband (a webster) for weaving equipment, indicating her continued interest in his affairs and possibly her continuing of his business after his death. ${ }^{25}$ In other pleas she was simply called Margaret de Stapulton. ${ }^{26}$ Similarly, Joan Samon featured in various debt pleas as both plaintiff and defendant, and was referred to as widow and executrix of Richard Samon, widow of Richard Samon, and by her full name. The first of these descriptions was applied when she faced claims for the payment of debts owed by her late husband (who had died in the previous year) in 1394, and referred directly to her legal responsibility as Richard's executrix. ${ }^{27}$ In other debt suits concerning house rent and the dying of cloth, she was simply called Joan Samon, as these activities were not related to the fact that she was a widow.

This inconsistency in recording the names of individual women was relatively common but only becomes apparent when we pay close attention to the way that women's identities were recorded in different cases. Agnes Chadwyk, Margaret Derby, Margaret Tailour and Margaret Thurston were all interchangeably recorded as "vidua" and by their full

${ }^{24}$ CA1291 rots.4d, 5, NA. Matilda and Hugh agreed with permission of the court, and Hugh was amerced $3 \mathrm{~d}$.

${ }^{25}$ CA1291 rot.13d, NA.

${ }^{26}$ John de Rossyngton v Margaret de Stapulton; John de Lyndeby v Margaret de Stapulton. CA1291 rot.26, NA.

${ }^{27}$ CA 1294 rot. 1, CA 1295/I rots. 4, 5, 5d, 7d, NA. 
names in the court book for $1491-2 .{ }^{28}$ Alice Tumby was recorded as wife of John Tumby, as well as by name alone, in the various stages of a trespass plea brought by Henry le Cancur, son of Ralph le Cancur, in $1323 .{ }^{29}$ In the same year, a drawn-out dispute concerning the detention of a strong-box by Geoffrey le Lockesmyth named the plaintiff variously as Emma, daughter of Roger le Brynkhull and Emma de Brinchull (with various spellings) over the course of at least eight different court sessions. ${ }^{30}$

The examples of Margaret Stapulton and Joan Samon, whose widowed statuses were sometimes central to their dealings with their late husbands' debts, demonstrates how the differing labels affixed to women's names could be specific to the nature of the case they were involved in. This is particularly notable where women performed the specific legal function of executor. Elizabeth, wife of Robert Oldham, late wife and executrix of William Johnson de Nottingham, brought a plea of debt for $£ 610$ s. together with her new husband (Oldham) against John Strelley, "gentilman", in 1492. Here we see the dual nature of Elizabeth's marital status as a remarried widow, as she was both the former and current wife of two different men. The money they sought was probably originally owed to Elizabeth's late husband, became her responsibility as his executrix, with her subsequent remarriage then necessitating the joint suit of husband and wife. ${ }^{31}$ The label of executrix denoted a specific legal status, upon which the validity of a particular case could hinge, and was used more consistently than other descriptors. Where legal action was directly related to a woman's (often recent) widowhood and the change in legal roles this brought, her widowed status was

\footnotetext{
${ }^{28}$ CA1374, NA.

${ }^{29}$ CA1258a rot.16, NA.

${ }^{30}$ CA1258a rots. $15,16,17,18,19,22,23,24$, NA.

${ }^{31}$ CA1374 rot.90, NA.
} 
more likely to be recorded, and it is these pleas that have more in common with the more notable presence of widows in litigation at common law. ${ }^{32}$

The descriptor "daughter" denoted a different type of not-married woman. Twenty one different women were described as such in 1335-6, though in 1322-3 only one daughter was recorded. Later samples feature no "daughters" as litigants, suggesting that this was a status identifier that fell out of official use, in line with the increasing proportion of women identified by only their full name. These were likely to have been young, unmarried women, probably still resident in the natal household and therefore known by association with their parents (usually the father), though the fact they were able to take part in litigation indicates that they had reached the age of majority. ${ }^{33}$ Most were involved in trespass pleas, demonstrating that they were perfectly able to get into trouble and have fights, but were not perhaps of an age or status to contract debts or extend credit. ${ }^{34}$ In 1335, sisters Emma and Juliana, daughters of Henry le Meirman, both separately claimed that Isolda Doget had assaulted them. Juliana also claimed that Isolda had stolen a hood and kerchief from her. Isolda brought a counter-suit, saying that Juliana had attacked her and drawn blood in the

\footnotetext{
${ }^{32}$ Stretton, "Widows at Law," 199-200.

${ }^{33}$ For daughters of burgesses, this was understood to have been when they became capable of carrying out the tasks required by a woman of her station, probably between the ages of 15 and 21. See Kim M. Phillips, Medieval Maidens: Young Women and Gender in England, c.1270-c.1540 (Manchester, 2003), 32-3.

${ }^{34}$ The same patterns have been noted for female adolescents in the countryside. See Judith M. Bennett, Women in the Medieval English Countryside: Gender and Household in Brigstock Before the Plague (Oxford, 1987), 67-76.
} 
town's marketplace. ${ }^{35}$ All three women claimed damages at the standard sum of 40s. The jury reported that both Isolda and Juliana had attacked one another, and both were awarded damages of $6 \mathrm{~d}$. But Emma was amerced for bringing an unjust complaint against Isolda, failing in what may have been a concerted attempt by the two sisters to harm Isolda through litigation. ${ }^{36}$ There were at least four Meirman siblings who featured in a range of complaints, including brothers William and John. In contrast to their sisters' trespass suits, the brothers were parties to various debt pleas in the same year, and the differing nature of these suits suggests that the brothers were of a relatively superior economic status to their sisters, allowing them to participate in the credit networks of the town, occasionally leading to debt litigation. The sisters' experience of the law, meanwhile, was as a result of their misbehaviour and the breakdown of interpersonal relationships ${ }^{37}$ However, being classified as daughters did not mean that these women were unable to take independent legal action; this was not a sign of wardship or of being "covered" by their father, but rather an indication of youth and familial status, as it also was for their brothers. ${ }^{38}$

The label of "singlewoman" emerged at a specific chronological moment. Judith Bennett and Amy Froide have suggested that approximately 10-20 per cent of adult women occupied this never-married status at any one time, but this descriptor only appears in the

\footnotetext{
${ }^{35}$ CA1262 rot. 12 , NA.

${ }^{36}$ CA1262 rot.13, NA.

${ }^{37}$ For example Margery of Quarndon v John son of Henry le Meirman - debt of 4s. 8d. for service. CA 1262 rot.16, NA.

3870 per cent of women described as daughters in medieval Douai were acting independently. Kittell, "Women's Social Identity in Medieval Douai,” 222.
} 
Nottingham court records from the end of the fifteenth century. ${ }^{39}$ In 1495, Margaret Sydall, "synglewoman", sued John Sye in the borough court for a debt of 6s. 10d. ${ }^{40}$ The following year, Alice Spenser, “singlewoman”, brought a plea of detinue against Emma Spenser, "vidua". ${ }^{41}$ In this second example we see a distinction between two types of singleness, the singlewoman and the widow, and the hierarchical contrast of "ever-married" and "nevermarried" women. ${ }^{42}$ The title also first appeared in the presentments of the sessions jury, a form of local policing, from $1495 .^{43}$

By the end of the fifteenth century, more descriptors were also being applied to men, with the majority being documented according to their occupation, such as John

${ }^{39}$ Judith M. Bennett and Amy M. Froide (eds.), Singlewomen in the European Past, (Philadelphia, 1999), 3; Judith M. Bennett and Christopher Whittick, "Philippa Russell and the Wills of London's Late Medieval Singlewomen," The London Journal 32, no. 3 (2007): 253-4.

${ }^{40}$ CA1375 106, NA.

${ }^{41}$ CA1377 13, NA.

${ }^{42}$ Butler, "Medieval Singlewomen," 62.

${ }^{43}$ Joan Litster de Baceford, singlewoman, presented for buying and selling grain at illegal measures. W.H. Stevenson, Records of the Borough of Nottingham, vol. 3 (London, 1889), 36. In York the title singlewoman also appeared from the 1480s onwards: Beattie, Single Women, 131-2. London women were also described as singlewomen slightly earlier in the Sheriffs' court records of 1461-2: Matthew Frank Stevens, “London Women, the Courts and the 'Golden Age': A Quantitative Analysis of Female Litigants in the Fourteenth and Fifteenth Centuries," The London Journal 37, no. 2, (2012): 67-88, 78. 
Hollyngworth, baker, or Nicholas Hyll, "alablasterman". ${ }^{44}$ The titles of "gentilman" and "husbondman" also first appeared at this point. ${ }^{45}$ The Statute of Additions of 1413 required that pleas in the royal courts recorded details of occupation ("estate or degree, or mystery") as well as place of residence and is likely to have influenced practice in these lower courts too. ${ }^{46}$ It has been suggested that this did not technically encompass female marital status, instead defined as a "condition", though the increased use of all titles and epithets may have been a wider result of the law of additions. ${ }^{47}$ There was generally a strict gender division in this recording of status: few women had their occupations added to their names, instead being described according to their marital status, reflecting the power of coverture. Marital status was understood to be the dominant facet of women's identity, but women's identities were also less defined by their occupations as many women worked in more than one trade and were generally excluded from entry into skilled or professional trades via apprenticeship or education. ${ }^{48}$ Some, such as Isabella Arden "wydowe and capknytter", were given both

${ }^{44}$ CA1374 12, 1491-2; CA1375 10, 1494-5 (all NA).

${ }^{45}$ e.g. John Misterton gentilman; Thomas Stevens de Horlay husbondman. CA1375, 1494-5.

${ }^{46}$ Edward Powell, Kingship, Law, and Society: Criminal Justice in the Reign of Henry V (Oxford, 1989), 67, 136.

${ }^{47}$ J.H. Baker, "Male and Married Spinsters," The American Journal of Legal History 21, no. 3 (July 1977): $255-9$ at 258.

${ }^{48}$ Maryanne Kowaleski, “Women’s Work in a Market Town: Exeter in the Late Fourteenth Century," in Women and Work in Preindustrial Europe, ed. Barbara A. Hanawalt (Bloomington, 1986), 157. See also Jonas Lindström, Rosemarie Fiebranz and Göran Rydén, “The Diversity of Work" in Making a Living, Making a Difference: Gender and Work in Early Modern European Society, ed. Maria Ågren (Oxford, 2017), 26. 
descriptors. ${ }^{49}$ The use of the English "wydowe" alongside Isabella's occupation represents another peculiar scribal choice, as all other widows were described using the various Latin terms. Perhaps Isabella's status was noted in English due to the dual nature of her identity alongside "capknytter", which did not easily translate. The occupations of others, such as Margaret Midwyff, were indicated by their surname. ${ }^{50}$

Cordelia Beattie has argued that marital status had to be performed in order to be visible: it involved "living as a single person", or as a married person - within a couple. ${ }^{51} \mathrm{We}$ find evidence of this in the court rolls, though this is also mediated by the ways in which women's marital status was documented by court scribes. The samples and examples discussed here reveal both the dominance of marital status as a general delineating principle for women's status, while also making clear that court officials did not follow a strict or consistent means of describing women according to the tripartite life cycle model. The understanding of the limits on married women's litigation, as dictated by coverture, resulted in a general cultural-legal framework in which women were identified as married or not married, though additional details beyond this were not defined by a consistent or fixed set of rules. There may have been an element of individual choice in the recording of individuals' status, or changes in policy and language, but these variations were also in part dictated by pragmatic concerns reflecting the nature of women's litigation in different cases. If she was married, she was required to plead with her husband; if a dispute related to her role as widow or executrix then these details would be recorded; if she was still living within the natal

\footnotetext{
${ }^{49}$ She sued John Smyth de Langley in 1492 for a debt of 4s. NA CA1374 136.

${ }^{50}$ CA1370 137, NA.

${ }^{51}$ Cordelia Beattie, "Living as a Single Person: Marital Status, Performance and the Law in Late Medieval England," Women's History Review 17, no. 3 (July 2008): 327-40 at 334.
} 
household, she might be termed "daughter"; and if none of these factors applied, she might be recorded by her name alone.

\section{LITIGATION AND THE MARITAL PARTNERSHIP}

The following section of this study draws specifically on married women's litigation in Nottingham to examine how this was defined by coverture and the role that married women took within litigation. ${ }^{52}$ Complaints of debt and trespass will be dealt with here in turn to allow for comparison of the different reasons that women ended up in court.

\section{Economic litigation}

Disputes arising from credit transactions were central to the negotiation of the commercial ties of credit and debt that underpinned the urban economy. The Nottingham court rolls reveal how women of all marital statuses made purchases, agreed credit, produced various essential goods, and bought and sold a range of services on a daily basis. The urban economy relied on credit agreements and deferred payment at all levels, from the purchase of household essentials to mercantile trade and wholesaling. Debt pleas therefore dominated the borough court and involved individuals - male and female - of all statuses who used the court to enforce or contest credit obligations. These pleas did not necessarily indicate financial crisis: being sued for debt could actually reflect commercial connections and

\footnotetext{
52 On Nottingham women in court see Teresa Phipps, "Gendered Justice? Women, Law and Community in Fourteenth-Century Nottingham," Transactions of the Thoroton Society 118 (2014): 79-92.
} 
integration, rather than an inability to pay. ${ }^{53}$ Women's debt pleas echoed the general characteristics of women's work as being lower status, more marginal and less professionalised than that of men, and their debts were, on average, of lesser value than those of men. ${ }^{54}$ Women made up 15-20 per cent of all economic litigants by the end of the fourteenth century, and debt accounted for over 60 per cent of women's litigious action. ${ }^{55}$

Many of these suits involved husbands and wives acting jointly as either plaintiffs or defendants, accounting for up to 50 per cent of women's economic litigation and revealing the economic partnership of marriage and wives' active role within this. ${ }^{56}$ This was not unique: married women were parties to litigation in the central courts, with thousands of

${ }^{53}$ For more on women and credit see Teresa Phipps, "Creditworthy Women and Town Courts in Late Medieval England" in Women and Credit in Predindustrial Europe, ed. Elise Dermineur (Turnhout, 2018), 73-94.

${ }^{54}$ On medieval women's work see Kowaleski, “Women's Work”, 145-164; Diane Hutton, "Women in Fourteenth Century Shrewsbury," in Women and Work in Pre-Industrial England, ed. L. Charles and L. Duffin (Beckenham, 1985), 83-99.

55 These statistics were calculated from full year samples of 1323-4, 1375-6, and 1394-5, drawing on a total of 965 suits. See Teresa Phipps, "Urban Women and Local Justice:

Gender, Society and Litigation in Fourteenth-Century England," (PhD diss., University of Nottingham, 2015), 113. On women and debt in other towns seeStevens, "London Women," 67-88; Stevens, “London's Married Women,” 115-132; Spence, “For His Interest?” 173-190; Kowaleski, "Women's Work in a Market Town,” 145-164.

${ }^{56}$ Phipps, "Urban Women and Local Justice," 120. On the marital partnership see Hanawalt, Wealth of Wives, 197-8. 
married women appearing in the Court of Requests in Elizabethan England. ${ }^{57}$ In the Court of Common Pleas during the fifteenth century, married women were also frequent litigants. In cases relating to London, three quarters of women's cases related to economic actions of debt, detinue or account, and 43 per cent of these featured a married woman as co-plaintiff or co-defendant. ${ }^{58}$ At the city's Sheriff's Court too, there was, according to Matthew Stevens, a "permissive attitude" towards married women's litigation. ${ }^{59}$ In medieval Scotland, married women prosecuted debtors both on their own and on their husbands' behalf, despite the fact that married women officially lacked the legal power to make contracts. ${ }^{60}$ However, the fact that numerous different types of court allowed wives to litigate with their husbands brings into question whether this was indeed a notably "permissive" practice, or part of a broader pattern whereby married women took part in legal action reflecting their role in the local economy and the marital partnership. Elsewhere coverture was more powerful in hiding wives' commercial roles behind the legal actions of their husbands: her debts were his responsibility. ${ }^{61}$ Craig Muldrew has argued that in early modern King's Lynn, credit transactions were recorded solely between men, obscuring the frequency with which women

\footnotetext{
${ }^{57}$ Tim Stretton, Women Waging Law in Elizabethan England (Cambridge, 1998), 135.

${ }^{58}$ Stevens, "London's Married Women," 117.

${ }^{59}$ Stevens, "London Women," 75.

${ }^{60}$ Elizabeth Ewan, "Scottish Portias: Women in the Courts in Mediaeval Scottish Towns," Journal of the Canadian Historical Association 3, no. 1 (1992): 27-43 at 39.

${ }^{61}$ Mate, Daughters, Wives and Widows, 187; Marjorie Keniston McIntosh, Working Women in England Society, 1300-1620 (Cambridge, 2005), 95.
} 
either lent or borrowed money, and underscoring "the lack of legal autonomy faced by married women." 62

The details of litigation show that wives' economic activity translated into legal action in a variety of ways. Much of the joint debt litigation by spouses, such as the case cited at the opening of this article, related to agreements made by wives during marriage, despite the fact that they could not, in theory, enter into contracts. Numerous complaints explicitly exhibit wives' agency both in agreeing transactions, and in enforcing these agreements in court in partnership with their husbands. ${ }^{63}$ Barbara Hanawalt's study of London wives acknowledges the business and legal actions of femme sole wives, but though there is no evidence that this special status existed in Nottingham, wives were nevertheless able to act as legal persons in litigating alongside their husbands revealing numerous agreements of differing nature ${ }^{64}$ In March 1391, Robert de Howedeyn and his wife Isabella complained that Tysson Braban had broken a covenant with them: Isabella had given him some thread to make into cloth for both Robert and Isabella, which Tysson had subsequently lost. ${ }^{65}$ Isabella was the key agent in this transaction, though the contract concerned cloth for both spouses. Emma Marchaunt sued Henry Prest and Katherine his wife in 1357, as she claimed that Katherine had agreed to spin

${ }^{62}$ Craig Muldrew, ““A Mutual Assent of Her Mind’? Women, Debt, Litigation and Contract in early modern England," History Workshop Journal 55, no. 1 (January, 2003): 47-71 at 54, 58.

${ }^{63}$ The economic partnerships of couples is also revealed in Chester debt pleas. See Jane Laughton, "Women in Court," 92.

${ }^{64}$ Hanawalt, Wealth of Wives, 278-281. Married women registered as femme sole (as if single) could trade independently of their husbands.

${ }^{65}$ CA1291 rot.13d, NA 
her wool for her, but Katherine had not done so in a good and competent manner, thereby breaking the covenant between them. Henry and Katherine both denied the claim of poor quality, and Emma sought damages of $40 \mathrm{~d} .{ }^{66}$ Here, it was Katherine and Emma who made the agreement, but because Katherine was married, the complaint involved both spouses. In March 1393, Thomas Fox complained that Richard Plattes and his wife Lucy owed him 11s. 6d. for "motley cloth" sold to Lucy almost two years earlier, again revealing the wife's agency in agreeing commercial transactions. ${ }^{67}$ These cases were not unique to medieval Nottingham; Cathryn Spence has also shown that debt cases in early modern Scottish burghs featuring husband and wife often related to instances where the wife was the principal actor. ${ }^{68}$ Other cases reveal a clear expectation that payments were owed jointly to both husband and wife. For example in January 1427, Thomas Lenton and his wife Alice sued John Lokyngton for detaining $5 \mathrm{~s}$. for rent since 1416 . Why the couple waited over 10 years to recover this debt is not known; they alleged that sum had been received by John from William Burton of Lowdham, to be paid to Thomas and Alice at Whitsun in 1416 but that had not been done. ${ }^{69}$

Not all pleas detailed the specific role of wives in credit transactions, but the fact that they were named as parties indicates that they nevertheless played a role in both the original

${ }^{66}$ CA1268 rot. $2, \mathrm{NA}$

${ }^{67}$ CA1292 rot.13, NA. Motley cloth probably referred to cloth woven from threads of multiple colours. See The Lexis of Cloth and Clothing:

http://lexissearch.arts.manchesterot.ac.uk/entry.aspx?id=3321, accessed October 2017.

Richard Plattes was a regular figure in the court and served as bailiff in 1389-90.

${ }^{68}$ Cathryn Spence, Women, Credit, and Debt in Early Modern Scotland (Manchester, 2016), 46-8.

${ }^{69}$ CA1328 rot.3d, NA 
transaction and the subsequent litigation. Women's commercial roles can often be inferred, particularly when complaints related to common forms of women's work, such as brewing. Married women dominated the industry in towns, where their profits could provide important additional income to the household economy. They also had access to the capital needed to invest in resources and equipment, through the household economy. However, brewsters' limited contractual independence and access to credit, highlighted by Judith Bennett, is reflected in joint pleas concerning various stages of the brewing process that saw husbands and wives in court together. ${ }^{70}$ In February 1402, Robert and Joan Glade complained that William Aschewe owed them 40d. for malt, which William acknowledged and paid along with 2d. damages. ${ }^{71}$ A few months earlier in October 1401, Thomas de Bothall and his wife Cecilia similarly claimed that Hugh Burges owed them 3s. for malt, plus damages of $12 \mathrm{~d} .{ }^{72}$ An inquest jury was summoned, though the result is not known. Laurence and Isabella Tyryngton sued Richard and Magota Grantham for 2s. owed for ale in $1375 .^{73}$ These married women took joint action with their husbands to recover debts that were probably accrued through their own engagement in the production and sale of ale. We know that these were not one-off activities, as both Robert Glade and Thomas de Bothall were fined for brewing against the assize in 1396, which may in fact have masked the brewing activity of their

\footnotetext{
${ }^{70}$ Judith Bennett, Ale, Beer, and Brewsters in England: Women's Work in a Changing World, 1300-1600 (Oxford, 1996), 24-30, 53-4.

${ }^{71}$ CA1299 rot.13, NA.

${ }^{72}$ CA1299 rot.2, NA

${ }^{73}$ CA1279 rot. 9, NA.
} 
wives. ${ }^{74}$ It is likely therefore that some of women's brewing work was similarly hidden beneath debt pleas between men.

Wives' involvement in economic litigation was not merely symbolic. They were expected to be present in court when named in a suit, or to follow the formal procedures that excused attendance or allowed representation by others, at least in the initial stages of litigation. These pleas therefore warrant greater attention than they have previously been accorded, as they show that wives were not merely adjuncts to their husbands. When William del Peek complained about a debt owed by John and Margery Cook, neither John nor Margery had shown up when required, and both were ordered to appear at the next court session two weeks later. ${ }^{75}$ In contrast, William de Brodbury and his wife Agnes sued Robert Squyer and his wife Isabella for debt in May 1393, and the roll records that both William and Agnes came "in their own person", but that Robert acted as attorney for Isabella. ${ }^{76}$ This was not an automatic “covering” of his wife but Robert's adoption of a formal legal role. However, the role wives played could also vary. In 1397, Richard and Lucy Plattes complained that John Russell owed them 12d. for various amounts of lead bought from them the previous year. ${ }^{77}$ The couple initially brought the plea together, but Lucy was not recorded in the subsequent court sessions. Husbands were, in some cases at least, able to continue a plea without their wives, though there must have been value in their initial inclusion in the plea. As Tim Stretton has argued, courts sometimes demanded the participation of women

\footnotetext{
${ }^{74}$ CA3492 rot.3, NA. Wives were rarely named individually for brewing against the assize at Nottingham.

${ }^{75}$ CA1291 rot.22, NA.

${ }^{76}$ CA1292 rot.16d, NA

${ }^{77}$ CA1296/I rot.12, NA
} 
when it was relevant to the case, even when, in theory, husbands could have litigated on their own. ${ }^{78}$

These cases all point to the practical role of wives in credit transactions during their marriage, and in the negotiation of these transactions and obligations within the borough court. Under coverture, they could not be held individually responsible for debts or contracts, though their legal partnership with their husbands extends the role of wives in debt and detinue suits beyond that of previous studies, where it has been suggested that wives' involvement in debt pleas stemmed from debts transacted prior to marriage. ${ }^{79}$ While medieval legal treatises did not deal with the practicalities of wives' roles in debt pleas, the seventeenth-century text The Lawes Resolutions of Womens Rights also suggested that wives' debts were only those contracted prior to marriage, implying that they would not be involved in transacting debts once married. ${ }^{80}$ Some Nottingham pleas were certainly rooted in these pre-marital debts. In an action for detinue of April 1492, Thomas and Margery Copeland complained that Thomas Higgin and his wife Joan detained numerous household goods from Margery since before her marriage. ${ }^{81}$ A similar debt plea of 1512 brought by Nicholas and Margaret Bowre referred to a debt owed to Margaret from the period while she was 'sole'. ${ }^{82}$ Some plaintiffs may have seen the marriage of previously single female debtors as an

\footnotetext{
${ }^{78}$ Stretton, Women Waging Law, 135-137.

${ }^{79}$ Stevens, "London's Married Women," 118-9, 129.

${ }^{80}$ T.E., The Lawes Resolutions of Womens Rights, (London, 1632), 213.

${ }^{81}$ CA1374 107, NA. “et postea predictus Thomas Copeland cepit in uxorem predictam Margeriam per quod action accrevit eisdem Thomae et Margeriae ad habendas et exigendas de prefato Thoma Hygyn et Joan exore sua predictas parcellas etc."

${ }^{82}$ CA1384 58, NA.
} 
opportune moment to recover their money. Equally, women may have waited until marriage to pursue complaints against others, particularly in relation to wages owed by previous employers, as the potential to sue jointly with their husband may have offered better prospects of a successful outcome ${ }^{83}$ However, the fact that details concerning pre-marital debts were rarely documented, with special justification recorded in these two instances, suggests that they were something of a departure from the norm, and that pre-marital debts did not lie behind the majority of wives' involvement in debt suits in Nottingham.

Wives' economic agency within the marital partnership did not always lead to them being named among parties to litigation, even when it is clear that they were central to the disputed transaction. These complaints accord more with Muldrew's picture of borough court litigation, where men acted on behalf of their wives, a pattern that Alex Shepard has also identified in early modern Cambridge. ${ }^{84}$ For example, in August 1367, John Baker complained that he had bought pair of millstones from Roger le Mason, by Agnes his wife, which Roger had failed to deliver. ${ }^{85}$ Agnes had agreed the purchase of the millstones to be made by Roger (a mason), on behalf of her husband (a baker), for whom the millstones were essential to his work. However, perhaps because she was only acting as his agent, when Roger broke the covenant Agnes was not involved in the plea. Various other cases followed this pattern. In 1357, Thomas Stanley complained that John Beeston owed him 27d. that

\footnotetext{
${ }^{83}$ Butler, "Medieval Singlewomen," 64, 67.

${ }^{84}$ Muldrew, "Women, Debt, Litigation and Contract," 54-7; Alex Shepard, "Manhood, Credit and Patriarchy in Early Modern England" Past and Present 167, no. 1 (May, 2000): 75-106 at 90-91.

${ }^{85}$ CA1276a rot.12d, NA.
} 
Agnes, Thomas's wife, had given to John in November 1354, to be repaid later in the year. ${ }^{86}$ In August 1408, Robert de Wodburgh sued Robert de Stapulton for a debt of 17d. that had been loaned to Robert de Stapulton's wife. ${ }^{87}$ Though we do not always know how or why these debts were contracted, these pleas identify the gap that could exist between married women's economic and legal agency as a result of coverture. Together, these cases demonstrate the lack of a consistent set of rules governing wives' involvement in economic disputes, ranging from significant personal involvement and agency to being "hidden" behind their husbands.

\section{Trespass litigation}

Trespass pleas were the second most common type of complaint in the borough court. They arose from the wide-ranging disagreements and misbehaviour that were inevitable features of urban life, and allowed monetary claims for damages to be sought as compensation for the harm caused by the actions of others. They concerned acts including assault, defamation, theft, housebreaking and damage to real and movable property. In fourteenth-century Nottingham, women featured in between $37-43$ per cent of trespass suits, accounting for 17-30 per cent of all litigants. Married women were regularly involved,

\footnotetext{
${ }^{86}$ CA1268 rot.1d, NA.

${ }^{87}$ CA $1304 /$ rot.23, NA.
} 
pleading with their husbands as both plaintiffs or defendants in 46-69 per cent of all cases featuring women. ${ }^{88}$

As plaintiffs, wives acted alongside their husbands to complain when they had been the victims of various attacks. For example, William Cancour and Avice his wife sued William de Wirsop for trespass and bloodshed in November 1364, claiming that William had assaulted Avice, and William was amerced by the court. ${ }^{89}$ Often, these complaints represented altercations between pairs of women. In October 1364, John Hester and his wife Joan brought a complaint of trespass and bloodshed against Roger of Grantham and his wife Katherine, alleging that Katherine had assaulted Joan and bloodied her against the peace. Both Roger and Katherine answered that Katherine was not guilty. ${ }^{90}$ Though they could not bring their complaints independently, neither did the women's husbands simply act on their behalf.

As the previous example demonstrates, women did not just appear in court as victims, but were also alleged to have committed these transgressions themselves, and the complaints of others clearly identify the independent misbehaviour of married women who were forced to take responsibility jointly with their husbands. In 1398, Joan Brailsford brought a plea of trespass against John Nottingham and his wife Margaret, claiming that Margaret had come to her house a few weeks earlier, assaulted her, dragged her and thrown her down, breaking the bone in her thigh. Presumably a serious injury such as a broken leg would have been common

\footnotetext{
${ }^{88}$ On women and trespass litigation see Teresa Phipps, "Misbehaving Women: Trespass and Honor in Late Medieval English Towns," Historical Reflections/Reflexions Historiques 43 (Spring, 2017): 62-76.

${ }^{89}$ CA1274 rot.4d, NA.

${ }^{90}$ CA1274 rot. $1 d$, NA.
} 
knowledge or easily evidenced in court, and the jury agreed that Margaret was guilty. ${ }^{91}$ Lady Alice Tannesley sued William Wade and his wife Alice in 1430, alleging that Alice had cut down and taken two damson trees from her garden, causing damages of $100 \mathrm{~s} .{ }^{92}$ William was eventually amerced 3d., suggesting he acknowledged his wife's misdemeanour and indicating his financial accountability as a direct result of her coverture. ${ }^{93}$ However, punishment could be directed specifically at wives. In October 1335, the jury found that Emma, wife of Roger Gaugy, had come to the house of Roger and Matilda Overandover and attacked Matilda. The court ordered that Emma be held in prison until damages of 12d. and the fine to the court could be paid.$^{94}$ Her imprisonment suggests that the couple did not have the money to pay the fine immediately, while also recognising that it was Emma who was responsible for the attack. Imprisonment as an outcome of these cases was rare, though in this case it demonstrates the separation of the legal identities of wife and husband in cases of misbehaviour.

Spouses also complained together about trespasses that had harmed them both, with damages reflecting the impact on the marital partnership. In 1330, Roger le Marchal and his wife Agatha complained that Henry le Marchal had attacked them both in John Dun's house. Henry had allegedly called Roger a false man and a thief and beat, trampled upon and maltreated Agatha, hitting her on the head with a dish, drawing blood and causing damages of 40s. The jury reported that Henry had beaten Agatha, and awarded damages of 40d.,

\footnotetext{
${ }^{91}$ CA1297 rot.3, rot.8, rot.10d, NA.

${ }^{92}$ CA1321/I rot.6d, NA.

${ }^{93}$ CA1321/I rot.8, NA.

${ }^{94}$ CA1262 rot.2, NA.
} 
though there was no verdict on the alleged verbal assault on Roger. ${ }^{95}$ Some complaints specifically cited the combined financial, physical and social harm for both spouses. In 1399, John and Alice Drapur sued William Asshewe for trespass, claiming that Alice had gone to William's house to collect various items that he had dyed for her (indicating some sort of commercial arrangement too), when William beat and "bore down on her" with abusive words. The claim for damages of 100s. cited the harm done to Alice as well as the shame that was brought on John, and though the jury reported a guilty verdict, the court awarded only 4d. compensation, a typical outcome of these complaints. ${ }^{96}$

The marital partnership, as represented under local law, therefore extended beyond the commercial ties and cooperation of husband and wife to their behaviour and interpersonal relationships too. The fact that these truly were joint pleas, rather than simply the symbolic recording of wives' names, is again evidenced by the separate essoins (excuses for nonattendance) of husbands and wives, such as Richard le Couper and Juliana his wife, defendants in a trespass plea brought by Richard Baldok in January $1325 .{ }^{97}$ When Ralph of Stanton, his wife Cecilia and daughter Margery complained about the behaviour of Margery widow of Robert de Esthill in 1335, all three members of the family were essoined separately by different men, clearly demonstrating the expectation that each litigant should be present at

${ }^{95}$ CA1261 rot.5, NA. This absence may mean that they only reported Henry guilty of the attack on Agatha, or the scribe may simply have chosen only to record one part of the verdict. 96 “despexit verbis contumelicis necnon.” CA1297 rot.23, NA. John also separately sued William for detinue of 12 pounds of woollen thread that he was meant to dye for him - this was presumably what Alice had gone to collect from William's house (called 'his place' 'ad locum').

${ }^{97}$ CA1259 rot.8, NA. 
court or formally excused.$^{98}$ In February 1434, William Stuward complained that John Annesley and Emota his wife had taken 40 pounds of animal skin from him. In responding to the complaint, John acted as Emota's attorney and replied that they were both not guilty, taking on the formal role of legal representative, just as any other male or female litigant might choose to do in appointing an attorney. ${ }^{99}$

Joint pleas were, therefore, part of established court practice and represented a pragmatic interpretation of coverture. However, a small number of examples show that married women could sometimes bring and answer complaints alone. In January 1491, William Cuymer brought a complaint of trespass against Agnes Gybson, wife of John Gybson. He claimed that she had come to his house with force and arms, breaking and entering and taking goods and chattels worth $3 \mathrm{~s} .{ }^{100}$ Agnes denied the attack, and the jury agreed. In 1495, Joan wife of Antony Lancaster complained that Thomas Orbney, "shomaker", had assaulted her with sticks and knives as well as "malicious words". ${ }^{101}$ Thomas also brought a successful counter-suit against Joan, claiming that she had assaulted him in his house. ${ }^{102}$ In neither of these complaints was there any indication that these women were acting incorrectly, suggesting that cases could continue if litigants overlooked these departures from usual practice. ${ }^{103}$ Yet in a handful of contrasting instances, these norms were challenged. Amya Litster attempted to sue Richard Brass for detinue of a cloak in 1397,

\footnotetext{
${ }^{98}$ CA1262 rot. 1 , NA.

${ }^{99}$ CA1324 rot.7, NA.

${ }^{100}$ CA1374 81, NA.

${ }^{101}$ CA1375 79, NA. Thomas was reported not guilty.

${ }^{102}$ CA1375 80, NA.

${ }^{103}$ Stretton, Women Waging Law, 129-135.
} 
claiming that she had loaned the cloak to Agnes, Richard's wife. However, Richard responded that Amya was in fact married to a man named Thomas Harbard, so he was not obliged to respond to her complaint. ${ }^{104}$ The outcome of this challenge has not survived, but we know that the court delayed further litigation while investigating the issue of Amya's marriage. Another woman, Agnes Halum, used a similar technique to get out of a trespass plea brought by William de Wyrsop in $1389 .{ }^{105}$ Litigation enabled women to perform their marital status, which itself determined their ability to take legal action, and these women were well aware of this fact. We only see the blurring of these lines when individuals were challenged in court, but these cases suggest that some other women, appearing in court alone and under their full name, might also have been married, further underlining the need for caution when categorising women and making assumptions about individual status.

\section{CONCLUSION}

Coverture had wide-ranging implications for Nottingham women's use of their local court. Their legal action was defined by a general framework that distinguished between the status and capabilities of married and not-married women. As a formal legal principle, coverture was rarely drawn upon as a justification or challenge to borough court litigation, demonstrating that its power was rather as a broad cultural understanding that informed the

\footnotetext{
${ }^{104}$ CA1296/I rot.21, NA.
}

${ }^{105}$ CA1290, NA. On the legal career of Agnes Halum see Teresa Phipps, "Female Litigants and the Borough Court: Status and Strategy in the Case of Agnes Halum of Nottingham" in Town Courts and Urban Society in Late Medieval England, ed. Richard Goddard and Teresa Phipps (Woodbridge, 2019): 00-00. 
nature of the marital partnership in both everyday life and under the law. In Nottingham, married women's litigation was not exceptional, but it was always informed by the culture of coverture. This resulted in joint actions by husbands and wives that did not render married women invisible or prevent them from claiming a legal identity, but was also specific to the circumstances under which women came to court. This mutability was also reflected in the way that the court documented women's identities, both in relation to marriage and other descriptors that helped to determine and document female status. Women were not rigidly or consistently classified under various marital categories, their identities instead being described in a more pragmatic manner that reflected their specific role in different legal complaints. The classificatory maid-wife-widow scheme may not have held as much sway in practice as the theoretical literature suggests.

Married women's litigation demonstrates the centrality of the marital partnership to the practical application of coverture, reflecting Craig Muldrew's argument that "it was not individuals but households which were successful, or which failed", despite the husband's legal control over material wealth. ${ }^{106}$ The range of commercial complaints that wives acted in reflects their key role in contributing to the household economy, but their role in litigation varied, ranging from the explicit recording of their individual agency in making agreements during and prior to marriage, to instances where their actions were more hidden or represented by their husbands. There was, therefore, an element of choice on the part of litigants in how to pursue disputes in which wives had played a role. This could offer some women a degree of legal agency that reflected their practical economic role. The legal ramifications of the marital partnership also extended beyond the household economy to complaints of misbehaviour that arose from wives' everyday interactions. Despite the legal

${ }^{106}$ Muldrew, "Women, Debt, Litigation and Contract," 53. 
responsibilities allocated to their husbands by coverture, many wives took an active role in the negotiation of relationships in court, as well as within the urban community more broadly. In addition, wives who were named as litigants were expected to participate or to be formally excused or represented by others. Taken together, women's roles and status across a range of complaints illustrate the pragmatic means by which the theoretical disabilities of coverture were negotiated in order to account for the reality of women's economic roles and the demands and disagreements that pervaded urban life. 